\title{
Project Based Learning (PjBL) Learning Model with STEM Approach in Natural Science Learning for the $21^{\text {st }}$ Century
}

\author{
Ika Rahmania \\ SMP Negeri 6 Malang, Indonesia \\ ikarahmania123@gmail.com
}

\section{Abstract}

The writing of this paper aims to discuss the learning of PjBL with the STEM approach to science learning in the face of the demands of the 21st century. The science learning model that is in accordance with the STEM approach is one of the Project Based Learning learning models. The STEM learning model with STEM approach is project-based learning by integrating STEM fields that can provide students with opportunities for contextual learning through complex activities such as exploring planning learning activities, implementing projects collaboratively, and ultimately producing a product outcome. The purpose of this paper will also describe the concept of STEM and the implementation of the STEM approach to science learning. The method used in this paper is a literature review by selecting several articles and journals regarding the STEM approach and its implementation in junior secondary education. In addition, a basic curriculum competency study of 2013 was conducted at the junior high school level that could be integrated into the STEM approach. The results of the study show that some basic competencies at the junior secondary school level in science learning can be integrated with the STEM approach in the form of activities to familiarize the STEM approach in the classroom and the provision of projects to students. Thus the implementation of the STEM approach at the junior secondary school level in science learning can be done in Indonesia in order to prepare competent human resources in facing the challenges of the 21st century. The Pjbl approach and STEM can shape students into human resources who are capable of critical and creative thinking, systematic and logical so as to be able to meet 21 st century human resource standards and be able to face increasingly complex global challenges.
Keywords

PJElearning, STEMapproad; 2lst century science learning

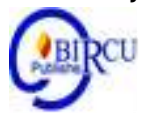

\section{Introduction}

Education that is carried out from time to time is always changing in accordance with the times. Therefore, teachers as learning managers are required to be more creative and innovative in order to make learning outcomes more optimal. This is in accordance with the Law of the Republic of Indonesia Number 20 of 2003, Article 1 paragraph 19, concerning the National Education System (Sisdiknas) that education is a conscious and planned effort to realize a learning atmosphere and learning process so that students actively develop their potential to have spiritual, religious, self-control, personality, intelligence, noble character, and skills needed by themselves, society, nation and state. (Simorangkir and sembiring, 2018) 
Progress a nation or a country is very much determined by qualified and competitive human resources (HR). To prepare quality and competitive human resources, education is a strategic tool. Education at this time must adapt to the characteristics of students who are demanded in the 21 st century.

The 21 st century national education aims to realize the ideals of the nation, namely the Indonesian people who are prosperous, happy, with an honorable and equal position with other nations in the global world, through the formation of a society consisting of quality human resources, namely independent individuals., willing and able to realize the ideals of his nation. In line with this, the Ministry of Education and Culture formulated that the 21st century learning paradigm emphasizes the ability of students to find out from various sources, formulate problems, think analytically and collaborate and collaborate in solving problems.

Based on his book 21stCentury Skills: Learning for Life in Our Times, there are several competencies and / or skills that 21 st century human resources must possess. In general, 21st century skills are divided into three skills, namely Learning and Innovation Skills. and Innovating), Information, Media, and Technology Skills (Technology and Information Media Skills) and Life and Career Skills (Life and Career Skills).

In the framework of preparing 21 st century humans who live in the nuances of a knowledge society and mega competition with such rapid waves of change, a learning model that is not only deductive but also inductive is needed. The learning model needed is one that can ensure that students have the skills to learn and innovate, the skills to use technology and information media, and be able to work and survive by mastering a number of life skills. There are several learning models that deserve to be applied in 21 st century learning. However, the most popular and widely implemented are the Project Based Learning (PjBL), Inquiry Based Learning (IBL) learning model, and the ones currently being intensively published are STEM Project Based Learning.

Project Based Learning is project-based learning where the learning process is studentcentered and provides a meaningful learning experience for students. Student learning experiences and concept acquisition are built on the products produced in the project-based learning process.

Apart from PjBL, current learning needs to keep up with the times in the era of globalization, one of which is by integrating Science, Technology, Engineering, and Mathematics (STEM). The relationship between science and technology and other sciences cannot be separated in science learning. STEM is a discipline that is closely related to one another. Science requires mathematics as a tool in data processing, while technology and techniques are applications of science. The STEM approach to learning is expected to produce meaningful learning for students through the systematic integration of knowledge, concepts and skills. Some of the benefits of the STEM approach make students better able to solve problems, innovators, inventors, independent, logical thinkers, and technological literacy.

Science learning with the STEM approach needs to be implemented in project-based learning units $(\mathrm{PjBL})$, in which students are challenged to be critical, creative, and innovative in solving real problems, which involve collaborative group (team) activities. In STEM-based learning students use science, technology, engineering, and mathematics in real contexts that connect schools, the world of work, and the global world to develop STEM literacy that allows students to be able to compete in the 21 st century.

Through PjBL-STEM learning, students will apply science, technology, engineering, math content to solve problems. Students will build new knowledge accompanied by developing skills and positive attitudes. 
This paper attempts to describe several things regarding STEM in Indonesia, namely how the concept and understanding of STEM and the implementation of the STEM approach in science learning at the junior high school level in facing the demands of the 21st century. STEM implementation design in science learning at the junior high school level. Apart from that the authors discuss STEM as an approach that can integrate aspects of STEM such as Science, Technology, Engineering and Mathematic.

\section{Review of Literatures}

\subsection{Project Based Learning (PjBL)}

The PjBL learning model emphasizes contextual learning through complex activities (Trianto, 2014), based on very challenging questions and problems and guides students to design, solve problems, make decisions, carry out investigative activities, and provide opportunities for students to work independently ( Wena, 2014). The use of this learning model involves project work where students will work to construct learning to then produce real products.

Project-based learning has the following characteristics (Kemdikbud, 2014). 1). Learners make decisions about a framework. 2). There are problems or challenges posed to students. 3). Students design processes to determine solutions to problems or challenges posed. 4). Students are collaboratively responsible for accessing and managing information to solve problems. 5). The evaluation process is carried out continuously. 6). Students periodically reflect on the activities that have been carried out. 7). The final product of the learning activity will be evaluated qualitatively. 8). Learning situations are very tolerant of mistakes and changes

According to the steps of the PjBL learning model are as follows: 1). Open the lesson with a challenging question (start with the big question) 2). Planning the project (design a plan for the project) 3). Develop a schedule of activities (create a schedule). 4). Oversee the course of the project (monitor the students and the progress of the project). 5). Assessment of the resulting product (assess the outcome) 6). Evaluation (evaluate the experience)

\subsection{Project Based Learning (PjBL) Science, Technology, Engineering and Mathematics- (STEM) in Science Learning \\ $\mathrm{PjBL}$ (project based learning) is a learning model suggested in the 2013 curriculum,} while STEM is more of a big strategy. There are similarities between the characteristics of PjBL and PjBL-STEM, but PjBL-STEM places more emphasis on the design process. The design process is a systematic approach in developing solutions to problems with welldefined outcomes (Capraro, et al., 2013). The PjBL-STEM learning process in guiding students consists of five steps, each step aimed at achieving a specific process. The following are the stages in the effective STEM-PjBL learning process (Laboy-Rush, 2010).

1. Stage 1: Reflection

The purpose of the first stage is to bring students into the context of the problem and inspire students to immediately start investigating / investigating. This phase is also intended to link what is known and what needs to be learned.

2. Stage 2: Research

The second stage is the form of student research. The teacher provides science learning, select readings, or other methods to collect relevant information sources. The learning process occurs more during this stage, student learning progress concrete abstract understanding of the problem. During the research phase, the teacher often guides the 
discussion to determine whether students have developed conceptual and relevant understanding based on the project.

3. Stage 3: Discovery

The discovery stage generally involves a process of bridging research and known information in project development. When students begin to study independently and determine what is still unknown. Some models from STEM-PjBL divide students into small groups to present possible solutions to problems, collaborate, and build cooperation among friends in groups. Another model uses this step in developing students' abilities to build a habit of mind from designing to design.

4. Stage 4: Application

At the application stage the goal is to test the product / solution in solving problems. In some cases, students test products made from predetermined conditions, the results obtained are used to correct previous steps. In other models, at this stage students learn a broader context outside of STEM or linking STEM field disciplines.

5. Stage 5: Communication

The final stage in each project is to create a product / solution by communicating between friends and class scope. Presentations are an important step in the learning process for developing communication and collaboration skills as well as the ability to receive and apply constructive feedback. Often the assessment is based on the completion of the final steps of this phase.

\section{Results and Discussion}

\section{STEM Implementation in Natural Science Learning}

In Indonesia, specific implementation guidelines regarding STEM education and approaches are not yet available. However, there are several educational institutions that have applied it in the education system, one of which is the Sampoerna School System. This is what makes their education system different from the curriculum used by other public schools. Currently, Indonesia is preoccupied with the latest curriculum, namely the 2013 curriculum, which was revised in 2017. There are several differences from the previous curriculum where this curriculum emphasizes critical thinking, higher-order thinking, creative thinking, problem-solving skills, Strengthening Character Education (PPK) and literacy.

In the latest curriculum implemented in Indonesia, there are many aspects that allow STEM implementation to enter into it. In the STEM approach, students are required to always be active in class, both hands-on activity and minds-on activity. The use of technology and information is always required in its application. Independent learning and learning based on the latest issues that occur in society are mandatory in implementing STEM. The STEM approach is in line with the principles of preparing RPPs in the 2013 edition of the 2017 curriculum revision.In the planning principle, student-centered learning. Learning is designed in such a way that students can explore themselves and issue ideas and opinions regarding learning material. Another principle is present-day orientation, in which teachers as facilitators are required to be "technologically literate", constantly updating and upgrading knowledge in their fields of expertise so that they can motivate students to continue to innovate (Kemendikbud, 2017). There is a conceptual framework for the STEM approach at each level of education. At the early education level, implementing the STEM approach is only limited to generating and stimulating the curiosity of students through activities that support this process. At the elementary school level, investigative and exploration activities.Furthermore, at the basic education level, students are exposed to the basics of 
STEM knowledge and relate their knowledge to situations of everyday life through investigative and exploration activities. Furthermore, At the junior high school level, the potential of students is explored by providing guidance and capacity building in the STEM field through analysis of local and global issues in solving problems. Whereas at the senior secondary level, STEM education focuses on strengthening and enriching abilities in the STEM field through activities to explain the STEM concept at a higher level..

Based on the basic competency analysis in the 2013 curriculum, science and mathematics can be integrated into learning in Indonesia, especially at the junior high school level. The integration of the STEM approach to the two subjects is based on the basic competencies of each subject so that in one lesson two basic competencies will be achieved at once. This can be time efficient. In addition, students can learn based on problems that occur everyday by using more than one STEM subject so that meaningful learning occurs. In addition, the integration of STEM subjects can be done by combining science and engineering even though engineering subjects are not framed in certain basic competencies in the curriculum.

Research on PjBL-STEM has been conducted before on science learning, with different dependent variables. Research by Afriana, et al. (2016) show that PjBL-STEM can improve scientific literacy and interesting and motivating learning, help understand teaching materials, form creative attitudes, and students are increasingly aware of the importance of protecting the environment. The application of PjBL-STEM provides new experiences for students, giving rise to motivation and interest in studying the theme of air pollution. Ismayani (2016), revealed that PjBL-STEM can improve students' creative thinking skills. The learning that is applied is considered useful because in PjBL-STEM students are invited to carry out meaningful learning in understanding a concept and exploring through a project activity, so that students are actively involved in the process. This fosters students to think critically, creatively, analytically, and improve higher-order thinking skills (Capraro, et al., 2015). Tseng, et al. (2011), revealed that PjBL-STEM provides students with experiences in solving real problems with practical activities, so as to increase effectiveness, meaningful learning, and support future careers.

\section{Conclusion}

PjBL and STEM learning can train students' abilities and talents to face 21 st century problems. The results show that PjBL-STEM can improve scientific literacy, motivation, material understanding, creative thinking skills, effectiveness, meaningful learning, and support future careers.

The STEM approach is an approach that interconnects and integrates STEM subjects in order to create learning based on problems of everyday life so that it can train students to apply the knowledge learned in schools with phenomena that occur in the real world.

In implementing the STEM approach at the junior high school level, it can be done through assignments that require a prior study of the basic competencies that students want to achieve so that in a combination of integration of STEM subjects it can be in line with the applicable curriculum in Indonesia. Therefore, implementing the STEM approach at the junior high school level in science learning can be done in Indonesia in order to prepare competent human resources in facing the challenges of the 21 st century. 


\section{References}

Abd. Syakur. (2020). Improving the Eighth Grade Students' Listening Comprehension Achievement by using Dictation Techniques. Konfrontasi: Jurnal Kultural, Ekonomi Dan Perubahan Sosial, 7(3), 205-216. https://doi.org/10.33258/konfrontasi2.v7i3.116

Baran, M. \& Maskan, A. (2010). The Effect of project-based learning on pre-service physics teachers' electrostatic achievements. Cypriot Journal of Educational Sciences, 5, 243257.

BSNP. (2010). Laporan BSNP 2010.

Capraro, R. M., Capraro, M. M., Morgan, J. R., \& Slough, S. W. (2013). STEM ProjectBased Learning: An Integrated Science, Technology, Engineering, and Mathematics (STEM) Approach. STEM Project-Based Learning an Integrated Science, Technology, Engineering, and Mathematics (STEM) Approach. http://doi.org/10.1007/978-946209-143-6

Cook, K., Buck, G., \& Park Rogers, M. (2012). Preparing biology teachers to teach evolution in a project-based approach. Science Educator, 21(2), 18-30. Retrieved from https://eric.ed.gov/?id=EJ997503

Haryono. (2017). Teknologi pendidikan dan pembelajaran abad 21.

Ismayani, A. (2016). Pengaruh Penerapan STEM Project-Based Learning terhadap Kreativitas Matematis Siswa SMK. Indonesian Digital Journal of Mathematics and Education, III (4): 264-272.

Kılınç, A. (2010). Can project-based learning close the gap? Turkish student teachers and proenvironmental behaviours. October, 5(4), 495-509.

Kementerian Pendidikan dan Kebudayaan. (2017). Panduan Penyusunan Rencana Pelaksanaan Pembelajaran Sekolah Menengah Pertama. Direktorat Jenderal Pendidikan Dasar dan Menengah dan Direktorat Pembinaan Sekolah Menengah Pertama.

Kemdikbud. (2013). Ilmu pengetahuan alam untuk SMP/MTs kelas VII: Buku Guru. Jakarta: Kementerian Pendidikan dan Kebudayaan

Kemdikbud. (2014). Materi pelatihan guru implementasi kurikulum 2013 tahun ajaran 2014/2015: Mata pelajaran IPA SMP/MTs. Jakarta: Kementerian Pendidikan dan Kebudayaan

Laboy-Rush, D. (2010). Integrated STEM education through project-based learning. (Online), (www.learning.com/stem/whitepaper/integrated-STEM-throughProjectbasedLearning), diakses pada 10 Maret 2017.

Movahedzadeh, F., Patwell, R., Rieker, J. E., \& Gonzalez, T. (2012). Project-based learning to promote effective learning in biotechnology courses. Education Research International, 2012, 1-8. http://doi.org/10.1155/2012/536024.

Rais, M. (2010). Project-Based Learning: Inovasi Pembelajaran yang Berorientasi Soft skills.

Raven, P.H., Hassenzahl, D.M., \& Berg, L.R. (2013). Environment: international student version (eight ed). Singapura: John Wiley \& Son.

Simorangkir, F. and Sembiring, R. (2018). Effectiveness of Helped Mathematical Learning Media of Lectora Inspire on The Number Sense Ability of Fifth Grade Students of Elementary School in Substrate Materials. Budapest International Research and Critics Institute-Journal (BIRCI-Journal). P. 352-358

Stohlmann, M., Moore, T. J., Roehrig, G. H., Stohlmann, M., Moore, T. J., \& Roehrig, G. H. (2012). Considerations for Teaching Integrated STEM Education Considerations for 
Teaching Integrated STEM Education. 2(1). https://doi.org/10.5703/1288284314653

Sulistyaningsih, Sulam, K., Syakur, A., \& Musyarofah, L. (2019). the Implementation of 21

St Century Skills As the New Learning Paradigm To the Result of Student'S Career and Life Skills. Magister Scientiae, 46, 228-237. https://doi.org/10.33508/mgs.v2i46.2229

Syakur, Abd. (2017). Education For Sustainable Development (ESD) Sebagai Respon Dari

Isu Tantangan Global Melalui Pendidikan Berkarakter Dan Berwawasan Lingkungan Yang Diterapkan Pada Sekolah Dasar, Sekolah Menengah Dan Kejuruan Di Kota Malang. Eduscience, 1(1), 37-47.

Syakur, Abd, Junining, E., \& Sabat, Y. (2020). The Effectiveness of Coopertative Learning ( STAD and PBL type ) on E - learning Sustainable Development in Higher Education. Journal of Development Research, 4(May), 53-61.

Syakur, Abdul, Musyarofah, L., Sulistiyaningsih, S., \& Wike, W. (2020). The Effect of Project Based Learning (PjBL) Continuing Learning Innovation on Learning Outcomes of English in Higher Education. Budapest International Research and Critics in Linguistics and Education (BirLE) Journal, 3(1), 625-630. https://doi.org/10.33258/birle.v3i1.860.

Trianto. (2014). Model Pembelajaran Terpadu: Konsep, Strategi, dan Implementasinya dalam Kurikulum Tingkat Satuan Pendidikan (KTSP). Jakarta: Bumi Aksara.

Wena, M. (2014). Strategi pembelajaran inovatif kontemporer: suatu tinjauan konseptual operasional. Jakarta: Bumi Aksara. 